\title{
Research Note \\ Relationship between the size of Pseudamphithoides bacescui (Amphipoda, Gammaridea) and the size of pods of algae
}

Relación entre el tamaño de Pseudoamphithoides bacescui (Amphipoda,

Gammaridea) y el tamaño de las vainas de algas

\section{Sergio Cházaro-Olvera ${ }^{1}$, Esther Scheinvar-Gottdiener ${ }^{1}$ and Manuel Ortiz $^{1}$}

\begin{abstract}
'Laboratorio de Crustáceos, Facultad de Estudios Superiores Iztacala, Universidad Autónoma de México, A.P. 314, Tlalnepantla, Estado de México, México. schazaro@gmail.com

Abstract.- The ampithoids are benthic amphipods that are related to algae in shallow water. The aim of the present study was to determine, for the first time, the relationship between the size of Pseudamphithoides bacescui and the size of the leaves of algae used for the construction of the shelter in the Sisal Reef System, Mexico. The organisms were recovered manually, using SCUBA. The amphipods were collected from a 'pod' cut from the blades of foliaceous algae and coral rubble. The length and width of the pods were also measured in micrometers. Forty-one specimens of P. bacescui were collected. The amphipods were found in pods of Dictyopteris delicatula and Dictyota cervicornis. The average total length of males of P. bacescui in D. delicatula was $661.89 \pm 347.23 \mu \mathrm{m}$; the average length of females was $493.79 \pm 237.16 \mu \mathrm{m}$. The average total length of the males in D. cervicornis was less than $163.93 \pm 53.22 \mu \mathrm{m}$. The regression between the length and width of P. bacescui against the length and width of the leaf or pod of the alga showed a positive and significant relationship. Smaller individuals were found in D. cervicornis, and a larger size was found in D. delicatula. This study defined a mesograzer intraspecific variation in size, which has a great importance in the ecological dynamics of the host plant.
\end{abstract}

Key words: Peracarida, Ampithoidae, dictyotalean algae, pod, coral reef

\section{INTRODUCTION}

The order Amphipoda comprises approximately 9,732 species known worldwide, although only 359 species have been reported in the Gulf of Mexico (Horton et al. 2013). Over 150 species of the family Ampithoidae Stebbing, 1899, have been described in 12 genera (Myers \& Lowry 2003, Horton et al. 2013, Hughes \& Peart 2013), and 8 species have been documented from the Gulf of Mexico (LeCroy et al. 2009). The ampithoids are benthic amphipods that are related to algae in shallow water (Hughes \& Peart 2013).

The interactive effect of nest-building and feeding activities by kelp curler amphipods on particular blade tissues (e.g., meristems and the influence on growth rate) is not yet completely understood. It has been suggested that amphipod host-choice is strongly influenced by seaweed chemical defense and its value as a refuge against predators. For example, some ampithoids use dictyotalean algae, which are efficiently defended by nonpolar secondary metabolites (e.g., terpenoids) that deter large consumers such as omnivorous fish (Duffy \& Hay 1994).

The genus Pseudamphithoides was first described by Ortiz (1976), to receive the new species P. bacescui. Almost simultaneously, Amphyllodomus incurvaria Just, 1977 now P. incurvaria (Just 1977) was published, with primary information on the leaf-cutting action of the animal. Both are the only known species in the genus, which is endemic to the Gulf of Mexico and the Caribbean Sea (Barnard \& Karaman 1991, LeCroy et al. 2009).

The refuge building and grazing activities by ampithoid amphipods can have a strong impact on the life history of seaweed (Duffy \& Hay 2000). On other hand, within a host alga, the growth rates of blades vary, possibly affecting the residency of the amphipods. The aim of the present study was to determine, for the first time, the relationship between the size of $P$. bacescui and the size of the leaves of algae used for the construction of the shelter in the Sisal Reef System, Mexico.

\section{MATERIALS AND METHODS}

Amphipods were sampled in the Sisal Coral Reef System (SCRS), off the Yucatan Peninsula, SW Gulf of Mexico (Fig. 1). The SCRS is located at $21^{\circ} 20^{\prime} \mathrm{N}$ and $89^{\circ} 50^{\prime} \mathrm{W}$. The SCRS is situated in the Campeche/Yucatan Neritic region (Wilkinson et al. 2009), which forms part of the Inner Campeche Bank Reefs, and is an underwater extension of 
the Yucatan Peninsula that slopes gradually northwards for about $200 \mathrm{~km}$ and descends abruptly into the Sigsby Deep (Ortegon-Aznar et al. 2008).

The organisms were recovered manually, using SCUBA, and were placed underwater in hermetically-sealed plastic bags. After reaching the shore, a 1:1 formalin/alcohol solution was added to the plastic bags. The amphipods were collected from a 'pod' cut from the blades of foliaceous algae and coral rubble. Then, the amphipods were preserved in $70 \%$ ethanol and were transferred to glycerin for dissection and identification with a Motic dissecting microscope (SMZ175) at the Crustacean Laboratory, FES-Iztacala, Universidad Nacional Autónoma de México (UNAM).

The total length and width of the amphipods were measured. The length and width of the pods were also measured in micrometers $(\mu \mathrm{m})$ with a digital camera and software Omax 14MP USB 3.0.

The correlation between the total length and the width of the amphipods, between the total length of the amphipods and the length of the pods, and between the width of the amphipods and the width of the pods were evaluated. Statistical analyses were performed using potential and linear regression and the Pearson correlation index (Sokal \& Rohlf 2012). Additionally, an ANOVA ( $\alpha=0.05)$ was used to check the significance of the correlation index. The Mann-Whitney $\mathrm{U}$ test was used to determine the possible difference between the average total length and width between males and females. The statistics were calculated with SigmaStat ${ }^{\circledR}$ for Windows (Version 3.1, Systat Software, Inc.).

\section{RESULTS AND DISCUSSION}

Algae are the portable habitat of species of the genus amphipods Pseudamphithoides (Lewis \& Kensley 1982); also, the use of dictyotalean algae is mainly for defense against predators by the production of secondary metabolites such as terpenoids (Cerda et al. 2010). Forty-one amphipods of species Pseudamphithoides bacescui Ortiz, 1976 were obtained, of which, 29 were males and 12 were females. The amphipods were found in Dictyopteris delicatula J. V. Lamouroux, 1809, and Dictyota cervicornis Kützing, 1859. The greater abundance was found in D. delicatula with 29 amphipods: 20 males and 9 females. In D. cervicornis, 9 males and 3 females were found, of which, 4 males were found in kelp beds, and 2 males and 3 females were found on pieces of coral (Table 1).

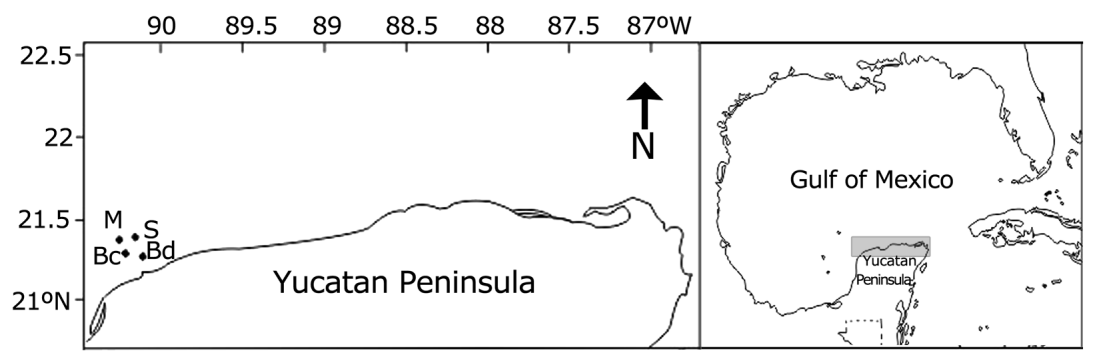

Figure 1. Location maps of the study area from Sisal Coral Reef System, Yucatan Peninsula. Bc: Bocacha, Bd: Bajo diez, M: Madagascar, S: Sisal / Localización del área de estudio en el Sistema Arrecifal de Coral Sisal, Península de Yucatán. Bc: Bocacha, Bd: Bajo diez, M: Madagascar, S: Sisal

Table 1. Pseudamphithoides bacescui. Number of males and females in each species of host and in each substrate / Pseudamphithoides bacescui. Número de machos y hembras en cada especie de hospedero y en cada sustrato

\begin{tabular}{lcccc}
\hline \multirow{2}{*}{ Host } & Sampling site / substrate & \multicolumn{2}{c}{ Gender } & \multirow{2}{*}{ Total } \\
\cline { 3 - 4 } & & Males & Females & \\
\hline Dictyopteris delicatula & Bajo diez / alga & 20 & 9 & 29 \\
Dictyota cervicornis & Sisal / Piece of coral & 4 & 0 & 4 \\
Dictyota cervicornis & Madagascar / alga & 3 & 0 & 3 \\
Dictyota cervicornis & Bocacha / Bed of seaweed & 2 & 3 & 5 \\
Total & & 29 & 12 & 41 \\
\hline
\end{tabular}


Other studies, such as Ortiz \& Lemaitre (1994), found P. bacescui on the Colombian Caribbean coast in prairies of the seagrasses Thalassia and Syringodium; Ortiz et al. (2007) reported this species in stomach contents of Haemulon sciurus (Shaw, 1803). On the other hand, Lewis \& Kensley (1982) found 97 individuals of $P$. incurvaria in Carrie Bow Cay, Belize, in Dictyota bartayresii and D. ciliolate. These authors mention that the pod constructed by $P$. incurvaria is believed to be a unique instance of a portable algal domicile, and that there is no mention in the literature of a domiciliary habit in the second species of Pseudamphithoides; however, this study shows a domiciliary habit of $P$. bacescui in D. delicatula and $D$. cervicornis. Finally, near the study area, Paz-Ríos et al. (2013) collected only one amphipod of $P$. incurvaria in the Alacranes reef on a Lobatus shell.

The average total length of males of the amphipods in D. delicatula was $661.89 \pm 347.23 \mu \mathrm{m}$, whereas the average length of females was $493.79 \pm 237.16 \mu \mathrm{m}$. The width of the body of the males was $55.47 \pm 40.43 \mu \mathrm{m}$, and was 66.92 $\pm 58.17 \mu \mathrm{m}$ in females. The average total length of males of $P$. bacescui in $D$. cervicornis was $163.93 \pm 53.22 \mu \mathrm{m}$. The average total length of males of the amphipods on pieces of coral in capsules of D. cervicornis was $138 \pm$ $38.18 \mu \mathrm{m}$, whereas the average of females was $139.03 \pm$ $27.23 \mu \mathrm{m}$. The average total length of males on kelp beds in capsules of $D$. cervicornis was $149.88 \pm 10.83 \mu \mathrm{m}$ (Fig. 2 ). The Mann-Whitney $U$ test showed that there was no significant difference between the total length of males and females $(P=0.699)$, and there was no significant difference between the width of males and females $(P=$ 0.572 ). However, there was a significant difference between the average total length and width of males in the 2 species of algae $(P=0.001)$. In addition, there was a significant difference between the average total length $(P=0.031)$ and the width of females $(P=0.016)$.

The size found for $P$. bacescui in this study ranged from 0.1-2.4 $\mathrm{mm}$, including the average size reported by Ortiz (1976). However, it is important to mention that, according to the results obtained in this study, individuals of a smaller size were found in D. cervicornis, and larger sized individuals were found in D. delicatula. In this
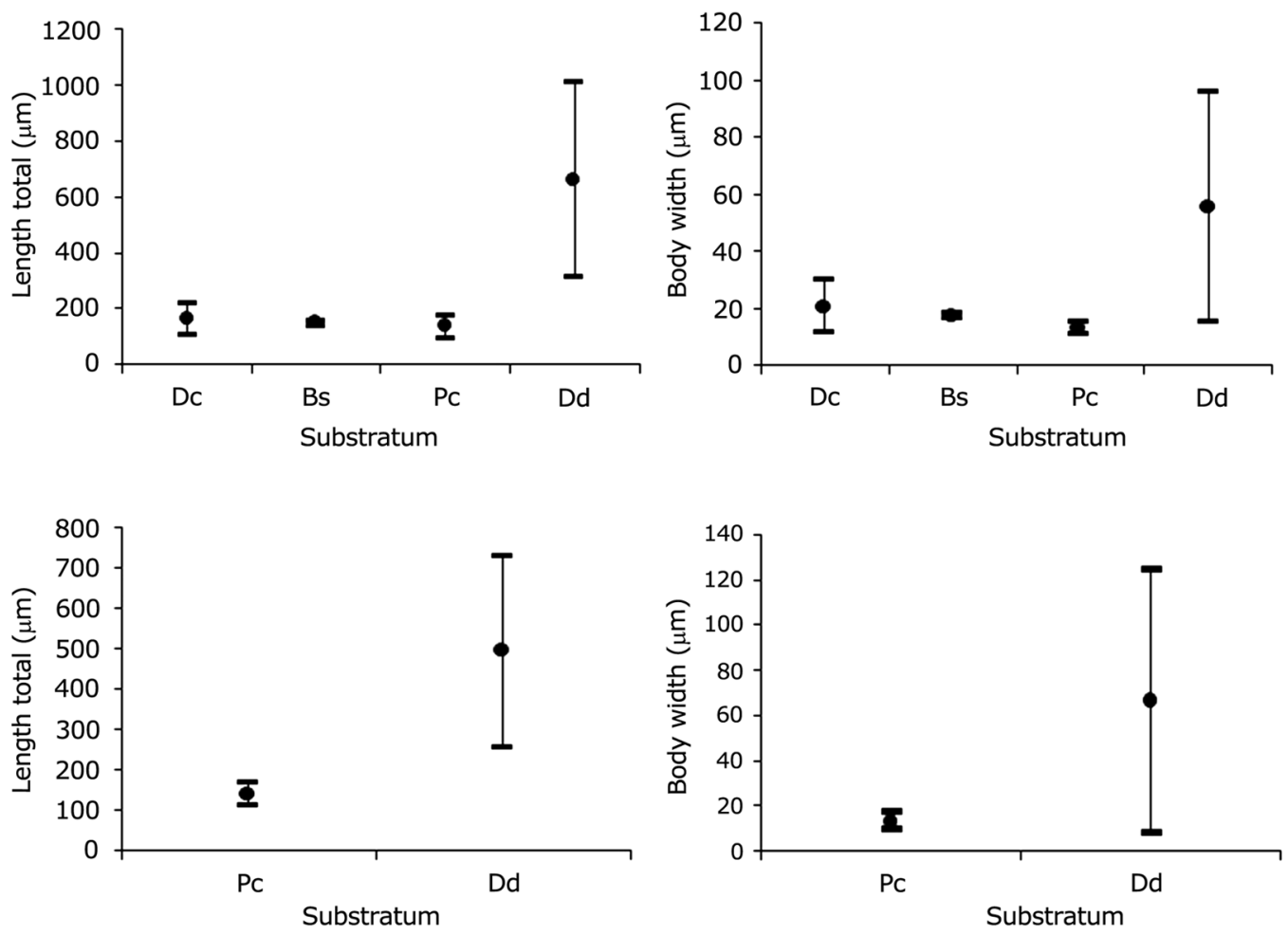

Figure 2. Pseudamphithoides bacescui. Total body length and width for each substrate. Dc: Dictyota cervicornis; Bs: Bed of seaweed; Pc: pieces of coral; Dd: Dictyopteris delicatula. A-B: males; C-D: females / Pseudamphitoides bacescui. Longitud total y ancho del cuerpo para cada sustrato. Dc: Dictyota cervicornis; Bs: Cama de algas; Pc: pedacería de coral; Dd: Dictyopteris delicatula. A-B: machos; C-D: hembras 
sense, functional differentiation among size classes may be particularly crucial in subtidal habitats, where mesograzers are dominated by isopods and amphipods (Duffy 1990), which may reduce competition between organisms of the same species.

The regression between the total length and width of the males and females of $P$. bacescui against the length and width of the pod D. delicatula, and the regression between the total length and width of the males and females of the amphipod against the length and width of the pod D. cervicornis, showed a positive and significant relationship $(P<0.05)$ (Fig. 3). Streissl \& Hödl (2002) also found a significant relationship between the size of the refuge against the length and width of Austropotamobius torrentium Schrank. Brawley (1992) suggests that an intraspecific variation in size mesograzer has great importance in the ecological dynamics of the host plant.
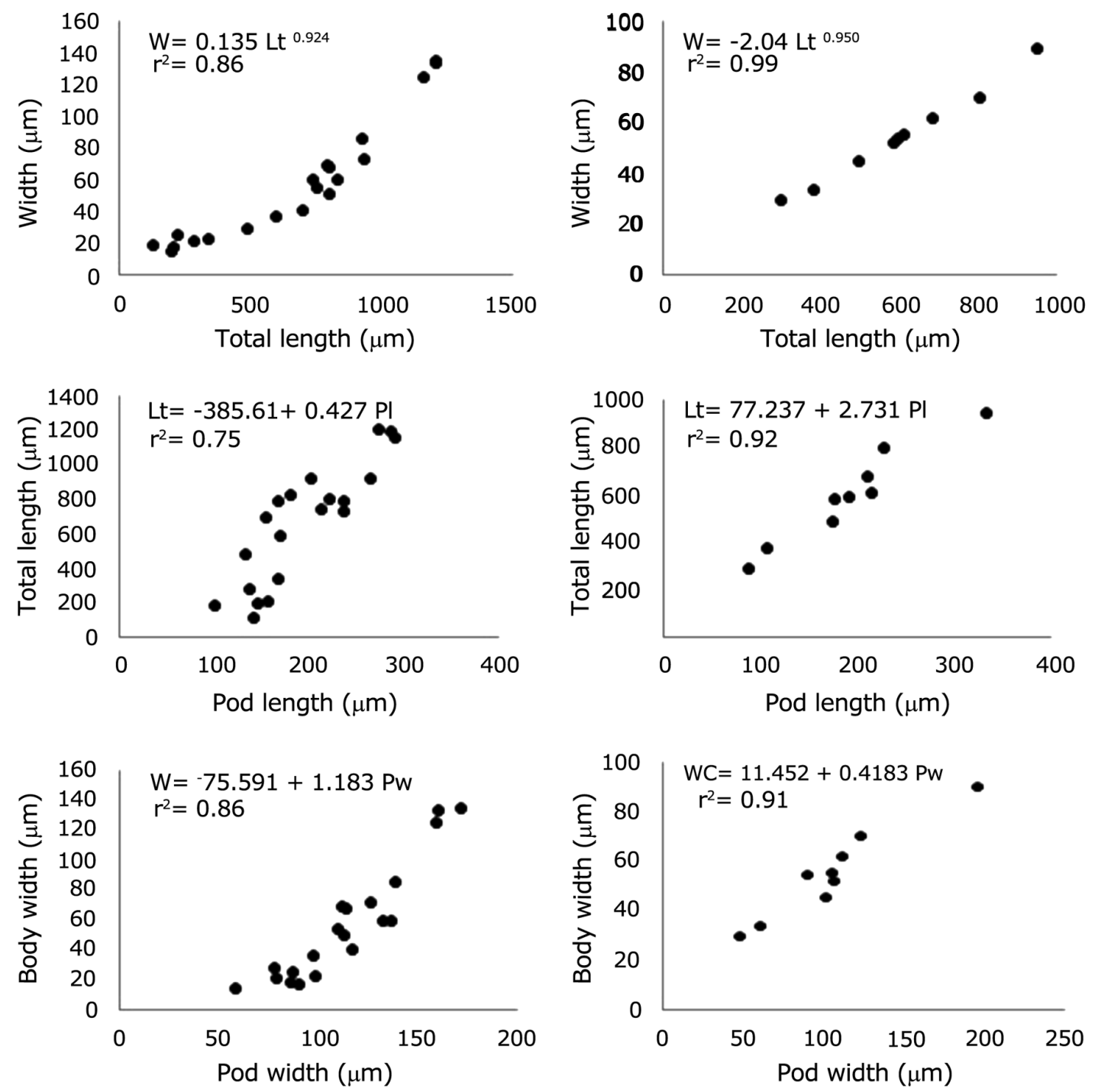

Figure 3. Pseudamphithoides bacescui. Relationship between total length (TI) versus body width (W), A) males and B) females; between pod length (PI) versus total length, C) males and D) females; between pod width (Pw) versus body width, E) males and F) females / Pseudamphithoides bacescui. Relación entre la longitud total (TI) versus ancho del cuerpo (W), A) machos y B) hembras; entre la longitud de la vaina (PI) versus longitud total, C) machos y D) hembras; entre el ancho de la vaina (Pw) versus el ancho del cuerpo, E) machos y F) hembras 
This study found significant differences in the size of P. bacescui in both species of alga, and Mancinelli \& Rossi (2001) mentioned that the crustaceans have morphological and behavioral differences; both are characterized by highly size-structured populations, where coexisting individuals can differ in size by more than one order of magnitude. The refuge availability can potentially determine levels of competition among individuals, affect population size and structure, and influence animal communities; also, structural characteristics of refuges, such as the size, shape, texture, and color, may also significantly affect refuge selection (Arsenault \& Himmelman 1998).

\section{ACKNOWLEDGMents}

We gratefully acknowledge the funds obtained through grants from the PAPIIT IN220715, FESI-PAPCA-2014-20 the authorities of the CONAPESCA-DGOPA (SAGARPA) for permits issued for scientific collection in Sisal and Puerto Progreso. In addition to the Port Administration, Puerto Progreso, Yucatán, for the facilities to collect bodies in federal zone. We would like to thank in particular Miguel Angel Lozano Aburto (Instituto de Ciencias Marinas y Pesquerías-UV) for field assistance.

\section{LITERATURE CITED}

Arsenault DJ \& JH Himmelman. 1998. Size-relate decrease in spatial refuge use by Iceland scallops Chlamys iislandica: ontogenetic behavioral changes or decreasing refuge availability? Marine Ecology Progress Series 162: 153-216.

Barnard JL \& G Karaman. 1991. The families and genera of Marine Gammaridean Amphipoda (Except Marine Gammaroids). Records of the Australian Museum, Suppl. 13: $1-866$

Brawley SH. 1992. Mesoherbivores. In: John DM, SJ Hawkins $\&$ JH Price (eds). Plant-Animal interactions in the marine benthos, pp. 235-263. Oxford University Press, Oxford.

Cerda OI, A Hinojosa \& M Thiel. 2010. Nest-building behavior by the amphipod Peramphithoe femorata (Krøyer) on the Kelp Macrocystis pyrifera (Linnaeus) C. Agardh from Northern-Central Chile. The Biological Bulletin 218: 248-258.

Duffy JE. 1990. Amphipods on seaweeds: partners or pests? Oecologia 83: 267-276.

Duffy JE \& ME Hay. 1994. Herbivore resistance to seaweed chemical defense: the roles of mobility and predation risk. Ecology 75: 1304-1319.
Duffy JE \& ME Hay. 2000. Strong impacts of grazing amphipods on the organization of a benthic community. Ecological Monographs 70: 237-263.

Horton T, C De Broyer, M Costello \& D Bellan-Santini. 2013. Ampithoidae Stebbing, 1899. In: Horton T, J Lowry \& C De Broyer (eds). World Amphipoda Database, World Register of Marine Species. <http://www.marinespecies.org/ amphipoda/> http://www.marinespecies.org/aphia. php? $=$ taxdetails\&id $=101366$

Hughes LE \& RA Peart. 2013. New species and new records of Ampithoidae (Peracarida: Amphipoda) from Australian Waters. Zootaxa 3719(1): 1-102.

Just J. 1977. Amphyllodomus incurvaria gen. et sp.n. (Crustacea, Amphipoda), a remarkable leaf-cutting amphitoid from the marine shallows of Barbados. Zoologica Scripta 6(3): 229-232.

LeCroy SE, R Gasca, I Winfield, M Ortiz \& E EscobarBriones. 2009. Amphipoda (Crustacea) of the Gulf of Mexico. In: Felder DL \& DK Camp (eds). Gulf of Mexico origin, water, and biota 1. Biodiversity, pp. 941-972. College Station, Texas.

Lewis SM \& B Kensley. 1982. Notes on the ecology and behaviour of Pseudamphithoides incurvaria (Just) (Crustacea, Amphipoda, Ampithoidae). Journal of Natural History 16(2): 267-274.

Mancinelli G \& L Rossi. 2001. Indirect, size-dependent effects of crustacean mesograzers on the Rhodophyta Gracilaria verrucosa (Hudson) Papenfuss: evidence from a short term study in the Lesina Lagoon (Italy). Marine Biology 138: 1163-1173.

Myers AA \& JK Lowry. 2003. A phylogeny and a new classification of the Corophiidea Leach, 1814 (Amphipoda). Journal of Crustacean Biology 23(2): 443-485.

Ortegon-Aznar I, H Leon-Tejera, M Gold-Morgan \& N Ramírez-Miss. 2008. Preliminary results on marine algae of Madagascar Reef, Yucatan, México: a functional group approach. Proceedings of the $11^{\text {th }}$ International Coral Reef Symposium, Ft. Lauderdale, Florida, pp. 1373-1376.

Ortiz M. 1976. Un nuevo género y una nueva especie de anfípodo de aguas cubanas (Amphipoda, Gammaridea, Ampithoidae). Ciencias Serie 8. Investigaciones Marinas 27: 3-12.

Ortíz M \& R Lemaitre. 1994. Crustáceos anfípodos (Gammaridea) colectados en las costas del Caribe colombiano, al sur de Cartagena. Anales del Instituto de Investigaciones Marinas de Punta Betín 23: 119-127.

Ortiz M, A Martin \& J Díaz. 2007. Lista y referencias de los crustáceos anfípodos (Amphipoda: Gammaridea) del Atlántico occidental tropical. Revista de Biología Tropical 55(2): 479-498. 
Paz-Ríos CE, N Simões \& PL Ardisson. 2013. Intertidal and shallow water amphipods (Amphipoda: Gammaridea and Corophiidea) from Isla Pérez, Alacranes Reef, southern Gulf of Mexico. Nauplius 21(2): 179-194.

Sokal RR \& FJ Rohlf. 2012. Biometry: the principles and practice of statistics in biological research, 937 pp. W. H. Freeman, New York.

Streissl F \& W Hödl. 2002. Habitat and shelter requirements of the stone craysh, Austropotamobius torrentium Schrank. Hydrobiologia 477: 195-199.
Wilkinson TAC, E Wiken, J Bezaury-Creel, T Hourigan, T Agardy, H Herrmann, L Janishevski, C Madden, L Morgan \& M Padilla. 2009. Marine ecoregions of North America, $200 \mathrm{pp}$. Commission for Environmental Cooperation, Montreal.

Received January 302015 and accepted 10 September 2015

Editor: Claudia Bustos D. 